\title{
Pakistan should properly adopt Urdu as its national language to help overcome inequality
}

Edition 7, 2021

Dr Hussain Mohi-ud-Din Qadri

DOI: 10.37839/MAR2652-550X7.19

A significant number of countries in the world have an official national language, which is used as the medium of instruction in schools and for official communication. Urdu has been the national language of Pakistan since 1948.

But Urdu has a particularly complex history in Pakistan-much more so than most other nations. In Pakistan, the so-called elite class widely uses English, and social status is largely judged through one's ability to express oneself in English.

Pakistan is a developing country and is striving to achieve socio-economic stability. On the UN's Human Development Index 2020 rankings, Pakistan was rated 154th out of 189 countries, putting it towards the bottom of the medium development category. The gross domestic product (GDP) per capita is USD1193.7, while 60 percent of the population lives on less than $\$ 2$ a day.

There is a strong link between the level of human development and a nation's education system. Robust education systems lead to a higher level of human development. The role of the medium of instruction in education is a key factor. Top economies of the world have each adopted their national language as the medium of instruction at all levels of education. 


\begin{tabular}{|l|l|}
\hline China & $\begin{array}{l}\text { Use of the national language as the official language and as } \\
\text { the medium of instruction }\end{array}$ \\
\hline Japan & $\begin{array}{l}\text { Standard Chinese or Mandarin (official; Putonghua, based on the Beijing } \\
\text { dialect), Yue (Cantonese), Wu (Shanghainese), Minbei (Fuzhou), } \\
\text { Minnan, (Hokkien-Taiwanese), Xiang, Gan, Hakka dialects, minority } \\
\text { languages. }\end{array}$ \\
\hline Germany & Japanese is the official language and widely used. \\
\hline France & French is the official language and 100\% used. \\
\hline Italy & Italian is the official language and widely used. \\
\hline Brazil & Portuguese is the official language and widely used \\
\hline Saudi Arabia & Arabic is the official language and widely used \\
\hline United Kingdom & English is the official and widely used language \\
\hline Russia & Russian is the official language and 85.7\% used in the country \\
\hline
\end{tabular}

\section{Source :}

https://www.infoplease.com/world/countries/languages-spoken-in-each-count ry-of-the-world

Pakistan's economy would be strengthened and inequality would be reduced if its national language was more widely used as the medium of instruction in schools and for official purposes.

Urdu is the most widely understood language and the lingua franca of Pakistan-virtually everyone speaks it (and there are approximately 300 million Urdu speakers in the world). According to Pakistan's 2017 census, 38.78 percent of people speak Punjabi, 18.24 percent speak Pashto, 14.57 percent speak Sindhi, 12.19 
percent speak Saraiki, 3.02 percent speak Balochi and 7.08 percent speak only Urdu. Other than these significant languages, somewhere in the range of 57 minor languages are additionally spoken all over the country.

In 1948, the founder of Pakistan, Mohammad Ali Jinnah, delivered a speech in Dhaka (then part of Pakistan) stating that Pakistan would have only one national language, Urdu, which would serve as the country's official language: all the official documents and administrative orders would be written and issued in Urdu.

However, successive governments made no arrangements to adopt Urdu as the official language and continued using English for official purposes. Most of the ruling class of Pakistan and other elites are graduates of elite English medium schools and English is widely seen as important in terms of foreign political, social and economic matters.

\section{The educational divide}

Knowledge can help a nation advance economically, politically and socially. Boosting literacy rates provides a solid foundation for an ideal democracy-if education is inclusive, the public gets the opportunity to develop economically and take a more active role in the nation.

However, there has always been significant social disparity in Pakistan: on the one hand the elite English-speaking class; and on the other people, who speak Urdu or any other regional language, who are considered 'unclean' and uneducated and who generally work for elites.

The schooling system in Pakistan is divided into three broad categories:

- Public sector educational institutions

- Elite and private-run English medium institutions

- Religious seminaries 
Those who have the resources and means to pursue a quality education choose to go to expensive privately-run English-medium schools. The majority of the underclass, particularly those belonging to the lower- middle and lower classes, are schooled in Urdu medium public sector institutions or have no option but to attend religious seminaries where, agai,n the medium of instruction is Urdu or a regional language.

Students educated at madrasas are not properly equipped with practical skills and have very limited career options, which generates resentment.

Urdu schools are under-funded and the teaching staff are generally not of as high standard as elite English schools. Consequently, students generally do not reach as high levels of academic achievement as students in schools where English is the medium of instruction. Those who manage to complete their education often find their lack of English skills are a barrier to employment. The number of students from Urdu schools who manage to gain admission to medical or engineering colleges or get into the civil services constitute a very small fraction of total enrolment in such schools compared with English medium elite schools. It's common for these students to suffer from a sense of inadequacy because of their socioeconomicallydisadvantaged backgrounds, in contrast with the alumni of elite English medium schools who commonly feel at ease holding senior positions in large companies or government.

\section{Unequal access to English learning creates a huge social divide}

Education has failed to be a unifying force in Pakistan, which is divided along ethnic, linguistic, racial and provincial lines. In fact, it has served to accentuate the class divide. There are approximately 2,60,903 schools in Pakistan with a total of $4,10,18,384$ students. If 908 billion rupees, which is the approximate educational budget of Pakistan, was spent on the education of all school-going children, each child's education would cost just 221 rupees, which is slightly above one dollar. Some 3.5 million children in Pakistan never attend school at all and work in quarries, 
mines, factories, fields, hotels and service enterprises. The government has no strategy to eliminate child labour and educate all Pakistani children.

In addition, 58 percent of state-owned Urdu medium schools in Pakistan do not have basic facilities such as toilets, furniture, fans and water. According to some studies, 18 per cent of teachers in state-owned schools get employment through political links, nepotism and bribery, rather than due to qualifications or a commitment to teaching.

In Balochistan, there are 12,000 state-owned schools and 7,000 of these only employed one teacher. In Punjab, 25 percent of schools remain totally or partially without basic facilities. Despite this funding shortfall, governments continue to financially support elite class English medium schools, which charge high fees.

\section{English is not generally well-taught outside elite schools}

Elite private schools teach most subjects, such as sciences and social sciences, in English, but in other schools, teachers tend to lack reading, writing, speaking, or listening abilities in English due to inadequate training and other opportunities. In addition, the syllabuses, teaching methods, assessment techniques and delivery of course materials vary greatly from school to school.

In 2013, 2014 and 2015, around half of all secondary school pupils failed English language subjects. In government-run secondary schools, the failure rate in English was 35.95 percent (2011-2015), whereas failure rates in Urdu and Pakistan Studies were as low as 2.2 percent and 3.61 percent respectively. In addition, 92 percent of those who took the Central Superior Services (CSS, or civil service) tests did not pass because their English was not good enough.

The implication of these figures is that, due to English being the main language in competitive exams, large numbers of students do not sit the exams and among those 
who do, the students who pass are mainly from elite English schools. This demonstrates the inequality between elite families and others who are unable to send their children to English schools. If Urdu was adopted as an official language for all these kinds of exams, competition would rise and the inequality gap would be reduced.

English and other subjects taught in English are prioritised by higher education institutions, so English skills are essential for students wanting to pursue higher education. Approximately 150 universities and colleges in Pakistan offer master's degrees in Urdu compared to almost twice that offering master's degrees in English. In addition, there are only seven highly recognised (known as y-category) Urdu research journals recognised by the Higher Education Commission, compared with many more in English; and only $461 \mathrm{Urdu} \mathrm{PhD}$ theses compared with more than 15,000 theses in English. English is main medium of thesis writing in all fields, except Urdu and Islamic studies, conducted from 1970-2021 in various public/private sector universities in Pakistan.

\section{Our national language needs to be properly adopted}

Genuine and serious efforts are needed to raise public awareness about the value of Urdu as the national language and to provide the groundwork for the replacement of English with Urdu. English continues to dominate the official working environment. English is used for executive, legislative, and judicial purposes even after 70 years of Pakistan's decolonisation and despite a Supreme Court ruling in 2015 that federal and provincial governments use Urdu for official purposes. Under this ruling, all government officials were required to deliver speeches in Urdu, even if abroad on an official mission, but then-Prime Minister Nawaz Sharif himself flouted the directive.

The world's top economies, with high standards of living and political power, take education delivered in the national language seriously. Those whose national 
language is not English, offer English and/or other international languages as optional subjects.

A high-quality education is required to develop creative and visionary minds. Most Pakistani students, even highly motivated ones who receive good marks in exams from rote learning, find it difficult to apply their knowledge to real world challenges. This explains why Pakistan cannot boast of many scientists, mathematicians and other critical and creative thinkers.

Pakistan's three-tiered education system produces predictable outcomes: graduates of religious seminaries take up careers in preaching, mainstream education leads to clerical and similar jobs, and elite English education produces students who take the highest-paying jobs with rank and honour.

\section{How to properly adopt Urdu as the official language of Pakistan}

The National Language Authority's revised recommendations in 2005 for the adoption of Urdu as the official language must be put into place as soon as possible. The Pak Urdu Schools system, set up by Minhaj Education Society, is an example of how this can be done. Students are taught all subjects using Urdu as the medium of instruction. English as a subject is compulsory, and in science-related subjects the technical and scientific terms are given in brackets in English, which will enable students to compete nationally and internationally.

Further, I believe the following action should be taken:

- The government should conduct all events, programmes, meetings and correspondence in Urdu.

- All documents of national importance should be translated into Urdu.

- Official forms related to government, semi-government and private institutions should be in the national language. 
- Books of all disciplines should be translated into Urdu (with technical terms retained in brackets in English).

- Translation bureaus should be set up in order to translate all books into Urdu, especially books on science and technology.

- Universities should offer translation studies programmes.

We need to promote Urdu as the national language of Pakistan because all nations advance materially, economically and scientifically when they educate students in their national language.

The author is chairman of the board of governors of the Minhaj Education Society and Deputy-Chairman of the board of governors of the Minhaj University Lahore.

Image: A street scene in Lahore. Credit: Francisco Anzola/Flickr. This image has been changed since publication. 